UDC 821.512.162

DOI https://doi.org/10.24919/2308-4863/37-2-17

\author{
Aysel MAHARRAMOVA, \\ orcid.org/0000-0002-1709-7609 \\ Junior Researcher at the Department of Research and Presentation \\ of Ancient and Medieval Azerbaijani Literature \\ National Museum of Azerbaijan Literature named after Nizami Ganjavi \\ of National Academy of Sciences of Azerbaijan \\ (Baku, Azerbaijan)lev.sabachka814@mail.ru
}

\title{
THE POETIC WORLD OF MUHAMMAD BIRIYA
}

The article discusses the life, activity and creativity of the South Azerbaijani poet Mohammad Biriya. The poet, who was an active participant in the National Liberation Movement in South Azerbaijan in 1941-1946, served as Minister of Education in the victorious National Government. Biriya, who emigrated to Baku after the fall of the Azerbaijani National Government, was later arrested and lived in exile for 24 years.

In this article, the researcher divides the poet's work into three periods: The first period covers the 30s and 40s of the XX century. During this period, satires occupied a central place in the poetry of the poet living in Tabriz. There is a strong sarcasm in these works, which are directed against fascism, its massacres in the world, as well as the local reaction that serves fascism. In his ghazals, which caricatured Hitler, the poet wrote his poetic thoughts about the war. At the same time, the lyrical poems he wrote about the freedom, nature and beauty of the Motherland have an important place in Biriya's poetry. The second period covers the 50s and 70s of the XX century. The work of the poet living in Baku during these years is full of contradictions. On the one hand, he praises the Soviet state and its work, and on the other hand, he complains about his time, his plight, and his life in exile. The poet was unjustly arrested twice and exiled to different parts of Russia. His poems written in exile in Kazakhstan are a good example of this. The third period covers the 80s of the XX century. These years are the poet's return to his homeland - Tabriz after a long and difficult separation. His writings before his arrest and death during his stay in Tabriz were little published, and it is impossible to write or comment on them because they are not available today.

The article also uses the works of People's Writer about Biriya, contemporary of Biriya Mirza Ibrahimov, Doctors of Philology Sabir Amirov, Islam Garibli about the poet, and quotes from them. Along with all this, the researcher Aysel Maharramova notes that Biriya's poetic work played an important role in the formation and enrichment of the whole Azerbaijani literature, its Southern branch.

Key words: Biriya, South Azerbaijan, Tabriz, Baku, poetry, homeland, exile.

Айсель МАХАРРАМОВА, orcid.org/0000-0002-1709-7609

молодиий науковий співробітник відділу дослідження та презентації античної та середньовічної азербайджанської літератури Національного музею азербайджанської літератури імені Нізамі Ганджеві Національної академії наук Азербайджану (Баку, Азербайджан) lev.sabachka814@mail.ru

\section{ПОЕТИЧНИЙ СВІТ МУХАММАДА БІРІЇ}

У статті розглядається життя, діяльність та творчість південно-азербайджанського поета Мохаммада Бірії. Поет, який був активним учасником Національно-визвольного руху в Південному Азербайджані в 1941-1946 роках, працював міністром освіти у переможному Національному уряді. Бірія, який емігрував до Баку після падіння азербайджанського національного уряду, пізніше був заарештований $і$ прожив у вигнанні 24 роки.

У иій статті дослідник ділить творчість поета на три періоди: Перший період охоплює 30-40-ті роки ХX століття. У цеей період сатири займали цеентральне місие в поезії поета, щуо мешкав у Тебрізі. У цุих роботах є сильний сарказм, спрямований проти фашизму, його різанин у світі, а також проти місиевої реакції, яка служить фашизму. У своїх газетах, які викрикували Гітлера, поет писав свої поетичні думки про війну. Водночас ліричні вірші, написані ним про свободу, природу та красу Батьківщини, мають важливе місце в поезії Бірія. Другий період охоплює 50-70-ті роки ХХ століття. Творчість поета, який у иі роки прожсивав у Баку, сповнена суперечностей. 3 одного боку, він хвалить радянську державу та ї̈ діяльність, а з іншого - скаржиться на свій час, важке становище та життя в еміграції. Поет був несправедливо арештований двічі $і$ засланий до різних куточків Росії. Хорошим прикладом иьього є його вірші, написані в еміграчії в Казахстані. Третій період охоплює 80-ті роки ХХ століття. Ці роки - повернення поета на батьківщину - Тебріз після тривалої і важкої розлуки. 
Його твори до арешту та смерті під час перебування в Тебрізі мало публікувались, і писати або коментувати їх неможливо, оскільки вони недоступні сьогодні.

У статті також використовуються твори народного письменника про Бірію, сучасника Бірії Мірзи Ібрагімова, докторів філологічних наук Сабіра Амірова, Іслама Гаріблі про поета та иитати з них. Поряд із усім цим дослідниия Айсель Махаррамова зазначає, що поетична творчість Бірії відіграла важливу роль у формуванні та збагаченні всієї азербайджанської літератури, ї̈ південної галузі.

Ключові слова: Бірія, Південний Азербайджсан, Тебріз, Баку, поезія, батьківщина, заслання.

Introduction. Life and environment. In the 1940s, especially during World War II, with the overthrow of the dictatorship of Reza Shah in South Azerbaijan (1941), new horizons opened up for the literary movement. The young writers, who joined the creative front, began to write historical works that reflected the socio-political environment, the monarchy, national discrimination, unemployment, fanaticism, and the massacres committed by Nazi Germany. Among these young people, M. Biriya also had a special place with his creativity and national activity. The new youth not only wrote works critical of the period, but also joined the revolutionary movement. They fought against the war in societies such as the 'Anti-Fascist' and prepared and distributed newspapers and leaflets. The special role of Biriya's ghazals in the creation of Hitler's caricature and sarcasm was undeniable.

Muhammad Biriya (1914-1985) was born in a poor family in Tabriz. According to him, in 1920 his parents moved to Baku to work. Biriya is studying at 7-year school No. 37 in Baku and then at the Petroleum Engineering College. They returned to Tabriz in 1931 due to his mother's illness and death.

Discussion. Biriya has to work in different places in Tabriz. He works as a clerk in the municipality, water department and 'Shahin' newspaper. A group of intellectuals who came to South Azerbaijan with the Armed Forces from Northern Azerbaijan in 1941 published the newspaper 'Vatan Yolunda' (in the way of homeland). Local writers, especially young people, also appeared in the newspaper from time to time. Biriya first worked for this newspaper, and in 1943 he began to publish a newspaper called 'Literature Page'. At the same time, Biriya works in the sociopolitical organizations and societies created against fascism and local reaction during this period. In 1943, Iran was elected chairman of the Azerbaijan Trade Union. He became a member of the Board at the First Congress of the Democratic Party of Azerbaijan. In 1945, he was elected a deputy from Tabriz constituency. Formed in December 1945, he became Minister of Education in the National Government. After the defeat of the National Government in December 1946, he also emigrated to Baku.

The Azerbaijan Democratic Party and published newspapers and magazines continued their activities in Baku. Biriya was appointed head of the propaganda department of the GDF. It is interesting that those who left their families, relatives in the South, mostly in Tabriz - B. Azeroglu, M. Gulgun, S. Tahir..., etc. could not stand Biriya, while they were rebuilding their lives in Baku and waiting to return. He repeatedly appealed to various organizations and departments to return to Tabriz, as a result of which he was arrested by the State Security Committee and sent into exile in Kazakhstan.

So, after the repression of 1937-1938, its second wave covered the years 1948-1953. This wave ended with the death of Stalin. And Biriya, like many others, fell victim to this wave - we are not mistaken.

The poet, who was acquitted in 1956, returned to Baku and again tried to go to Tabriz. This time he was deported to Russia with ten years in prison. When he returned, Biriya was not allowed to live in Baku and was sent to Shamakhi. In Shamakhi, the poet is a mullah because he knows the Qur'an and its verses. Academician, People's Writer Mirza Ibrahimov, who fought with Biriya on the same front in 1941-1946, writes in his memoirs: "Naturally, Biriya was a poet and public figure who was wholeheartedly attached to his people, homeland, literature and culture. His religious convictions were strong. Of course, there were those who did not want it, and there were villains. He was shot at a rally on Sattarkhan Street in Tabriz. " (Ibrahimov, 2007a:16) Then the People's Writer speaks about the poet's determination to return to Tabriz: “- I can't stand it! Understand me, my wife, my baby son have stayed there... "(Ibrahimov, 2017b: 19)

Another tragedy was that the family of the poet, who sacrificed himself for his family, homeland and people, did not understand him. Maybe if his wife had taken her son to Baku, Biriya would not have suffered so much.

After the Iranian revolution of 1978-1979 and the change of government, the poet was able to return to Tabriz in September 1980. However, he cannot meet his son because he is in France. His wife no longer accepts him. It was not long before the poet was arrested in Tabriz. Although people who had known him since the 1940s released Biriya from prison, the poet died in 1985 and was buried in Tabriz. Thus, the last moments of a poet, a patriot, who was connected 
with his family, who lived with 70 years of spiritual and physical sufferings and punishments, end in tragedy.

Main part. Creativity. Biriya's works were last published in Baku in 1910, compiled and prefaced by Doctor of Philology Islam Garibli and edited by academician Bakir Nabiyev.

We read in Islam Garibli's foreword 'Poet of Fate' that four books were published during the poet's lifetime. His first book 'Word of the Heart' was published in Baku in May 1944 in 'Azerneshr', the second book was published in Tabriz in 1944 under the title 'My Homeland Azerbaijan'. His 3rd and 4th books were also published in Tabriz in 1945.

Biriya's books began to be published 52 years after his death. First, in 1997, the Yazichi publishing house in Baku published a book entitled 'I have a grave at every step ...', and in the same year, the Erk publishing house in Tabriz published a book entitled 'Words of the Heart'. Later, in 2003, Biriya's 7th book 'Ambassadors of the Poet's Life' was published by 'Yurd' publishing house in Baku. (Biriya, 2003)

In the book compiled by Islam Garibli, poems were collected using Biriya's previous books and grouped according to their subject. The first part contains lyrical poems written by the poet at different times, the second part satirical poems, the third part poems, and the fourth part comedies and scenes. The book chronicles the most satirical poems written in the 1940s, exposing fascism. Most of the remaining poems, unfortunately, have no history. Only the content, the subject, where it is written is estimated.

The main style of the poet's poetry of the $40 \mathrm{~s}$ was satire. Satirical poems were at the forefront of the work of all poets who continued the traditions of patience in the South. Both old and young poets could satirically expose all the ugliness of the time, as well as fascist politics and Hitler's claim to world domination. Southern scholar Sabir Amirov writes in his research work: "Democratic poetry is an indisputable historical fact that from the time it took its first steps, there was an inexhaustible sympathy for satire and laughter in its work ...". (Amirov, 2000: 215-216) In this sense, the satirical poems of M. Biriya are especially noteworthy. The image of Hitler occupies a significant place in his poetic work of 1941-1945. It is enough to name these poems to make that poetic revelation clear: "Hitlerin"(Hitler's), "Dolaşma" (almanpərəstin dilindən) ('Don't Wander' (from the German language), "Hitlerçilərə"('To the Hitlerites'), "Mussolinin istefası" ('Mussolini's resignation'), "Vay Dədə" (Hitlerin dilindən) ('Wow' (from Hitler), "Hitlerin Mussoliniyə Pəyami" (Hitler's Message to Mussolini),"Xarkovun alınması münasibəti ilə Hitlerə" (To Hitler on the occasion of the capture of Kharkov), "Aman, dadıma gəl" (Hitlerin dilindən) (Help me from Hitler), "Hitlerin arzusu" (Hitler's dream), "Hitler, elə dərdlərivin çarəsin" (Hitler, let there be a solution to your problems), "Adolf Hitlerin soldatlarından şikayəti" Complaint of Adolf Hitler from soldiers), "Hitlerin ahu-naləsi"( Hitler's groan), "Xanəsini xərab edib çərxi zəmanə Hitlerin" (Hitler's time of harm) and dozens of such poems occupy a central place in the poet's work of the 1940s.

Consider a verse from a poem "Hitlerin ahünaləsi" (Hitler's groan):

I said in November that I would take Moscow from Russia,

I will make my way to the Caucasus from all sides, I ride on the boats in Bahri-Kasbi, I play the tar,

The wind blew me away, shame on me, I'm dying, I tremble again, and I am dying!.. (Garibli, 2010a :208)

Apparently, Hitler's great dream, the sequence of the plan of occupation, is ridiculed in the same sequence. Hitler's dream of capturing Moscow and then the Caucasus and playing tar on a ship in the Caspian Sea was dashed. As the Red Army captured the cities it occupied one by one, Hitler's evil days began:

The Russians took Kiev, and I was strangely shocked,

My heart is burning, let your turn return, $\mathrm{O}$ destiny! (Garibli, 2010b:226)

There is a high level of optimism in Biriya's poetry in the 1940s. The main place in his satires and lyrical poems is occupied by the beautiful future of the Motherland without enemies, its carefree future, its nature, cities, freedom and struggle. The poet looks at the future of the Motherland with great confidence: In his poems such as "Azərbaycan şürudu" (Azərbaycan nəğməsi) ("Azerbaijani consciousness" (Azerbaijani song)), "Urmu" (Urmiya) ("Urmu” (Urmia)), "Azərbaycan el marşı"( "Azerbaijan national anthem"), "Oziz vətənim Azərbaycan" ("My dear homeland Azerbaijan"), "Odlu, alovlu şairəm"( "My fiery poet"), "Vətən" ("Homeland"), "Tazə həyat istərəm" ("I want a new life"), "Q1z1l ordudur", "Cəlladlara baş əymədik"( "We did not bow to the executioners"), "Azad sovet qadınına" ("To the free Soviet woman"), "Mən nə deyirəm" ("What do I say"), "İstiqbalımız parlaqdır"("Our future is bright"), "Oziz vətənim Azəristana" ("My dear homeland is Azerbaijan "), the poet writes his sweet, great, inexhaustible dreams. The main idea, purpose and goal of his poems are as follows:

I say: - Let my homeland be free from the oppressor, 
Let me laugh like the gardens that have been destroyed ... country,

... I say: - Let the light of science shine in our

Let the hearth of ignorance be extinguished forever ...

... I say: - Let the dictatorship rot forever,

Let the beautiful light of freedom cover all sides. (Garibli, 2010c:68)

Thus, in the works of Biriya in the 40s, peace, humanity and attachment to the country are described and glorified at a very high level.

Even when he was in exile in Baku, the poet had many optimistic poems about Baku, the Writers' Union, individual writers and poets, the Soviet state, his work, as well as the great victories of the Red Army. This was probably due to the poet's great hopes and beliefs in this state and structure. The reader also believes very well in the sincerity of the verses in the poem 'Attack':

A red flag in one hand, a glorious weapon in the other,

Riding a horse on the chest of the Old West like Koroglu,

Try to attack again the heroic Red Army,

Bakhir trusts him and is proud of the Soviet country ... (Garibli, 2010d:106)

The poem tells about the victories of the Soviet army, which destroyed the German-fascist forces on the Western Front and crossed the border.

"... Biriya is, above all, a great lyric. M.Biriya's lyrics, skillfully benefiting from classical oriental poetry, as well as rich Azerbaijani folklore, breathe with time, and a number of great events of the time become the subject of his poetry with great skill and a bit of romantic pathos. (Garibli, 2010e:10-11) And, of course, the main idea of the poet is the Motherland and its freedom and integrity. This idea-content passes through Biriya's poetry like a golden line.

The life of a bad day should be less,

Let spring come, let the people be happy,

In the spring of nine months,

What is a cloud, what is fog, what is snow ?! (Garibli, 2010f:37)

During the one-year period of the national government, the poet wrote many lyrical poems about the homeland, its freedom and prosperity. 'Urmi', 'Open letter', 'Homeland' are of this type. The poem 'Homeland' is especially noteworthy:

My dream is always to be a homeland,

May tulips and flowers bloom, may the homeland be happy!

The country of Azerbaijan has been plundered a lot,
I want freedom to be permanent, homeland! (Garibli, 2010g:37)

The poems written by the poet during the years of exile are very different from those written in previous years. These poems are far from pathos, full of complaints about time, life and the world. Poems written in exile in Kazakhstan, such as 'How can I come', 'Homeland', 'Who am I', 'Longing for the homeland', 'Place', 'Rebellion', 'I have', 'I was created', 'Curse' are great rebellion of his heart against the intolerable laws of life: The life of heavy exile, far from their loved ones, not being heard from, has broken the poet a lot, offended and annoyed him with life and people.

The camp was surrounded by a fence, by God,

Defect wherever you look, by God,

It was a courage to get out of here, by God,

You say come home, how can I come?! (Garibli, 2010h:128)

He wrote to Colonel Mammadov 'What poem should I write?'. His poetic work is another clear example of what we have said. Biriya wrote this poem after 24 years of exile. The poetic pieces written by the great master of satirical and romantic words over the years are heartbreaking and heartbreaking. There is more madness, not solemnity, but supplication, desire for mercy in these poems. What did the poet not do to return to his homeland and family:

God has made my life difficult,

Sends Tambov, gives exile,

Let not the unbeliever live my life,

Colonel, what other poem should I write ?!

I wish in this regard,

I want help from a friend,

Get rid of this Russian from me,

Colonel, what other poem should I write ?! (Garibli, 2010i)

What else could a poet who had lived in exile in the great Soviet country he once sang for twenty-four years write:

Twenty-four years in the Soviet country ...

Separation has been a pain in my heart ...

It doesn't end with writing ...

Colonel, what other poem should I write ?! (Garibli,2010j:134-135)

Other verses of the poem are also pleading requests. This poem has a history: Baku, June 26, 1970. The poet, who returned from exile, says Tabriz again, he wants Tabriz: 'Biriya from Tabriz begs you, // Show me the Julfa bridge ... // I'm leaving, if you want I'll come again ...'

I think that the life, activity, creativity of Biriya and the state created by dividing a nation at that time, 
the laws that froze blood are a separate research work. In Mirza Ibrahimov's memoirs, this is revealed to some extent, but I think the memoirs are partially published. This also needs to be investigated. Because as an author of great novels, a patriot, a humanist, a writer in the midst of events, Mirza Ibrahimov could not write a memoir so incompletely and briefly.

Both poems by M. Biriya are included in the book. 'Legend of Erk Tower' and 'Hero of Azerbaijan'. The first poem speaks of the legendary love, its power, its power, its ability to create wonders, its miracle in human life. It is a love story of the master who built the famous, ancient Erk fortress. The second poem tells about the battle of the Azerbaijani hero Mikail, who took part in World War II, against the Nazis.

Conclusions. Thus, we took a brief look at the life and work of the famous master of words M. Biriya and determined that the poet's work is divided into three periods: The first period covers the 30 s and 40 s of the XX century. During this period, satires occupied a central place in the poet's poetry. They are works against fascism and local reaction. Lyrical poems written for the freedom of the Motherland and the beauty he loves also play an important role in his poetry. The second period covers the $50 \mathrm{~s}$ and $70 \mathrm{~s}$ of the XX century. During these years, the poet's work is full of contradictions. On the one hand, he praises the Soviet state and its work, and on the other hand, he complains about his time, his plight, and his life in exile. His poems written in exile in Kazakhstan are a good example of this. The third period covers the $80 \mathrm{~s}$ of the XX century. These years are the poet's return to his homeland - Tabriz after a long and difficult separation. His writings before his arrest and death have been poorly published, and we cannot speak at length because we do not have them today.

\section{BIBLIOGRAPHY}

1. Omirov Sabir. Cənubi Azərbaycan Milli - Demokratik ədəbiyyatı (1941-1990) Bakı:"Elm”, 2000, 257 s.

2. İbrahimov Mirzə. Biriyanın məhəbbəti və faciəsi. Cənubi Azərbaycan ədəbiyyatı: Tədqiqlər. IV kitab. Bakı: "ULU" İKF, 2017, $160 \mathrm{~s}$.

3. Qəribli İslam. Talesiz şair. Məhəmməd Biriya. Osərləri. Bak1: “Elm”, 2010, Səh. 4-27

4. M. Briya. Şair ömrünün elçiləri. Bakı: "Yurd”, 2003, 208 s.

\section{REFERENCES}

1. Omirov Sabir. Cənubi Azərbaycan Milli - Demokratik ədəbiyyatı (1941-1990) [National-Democratic literature of South Azerbaijan (1941-1990)] Baku: 'Science', 2000, 257 p.

2. İbrahimov Mirzə. Biriyanın məhəbbəti və faciəsi. Cənubi Azərbaycan ədəbiyyatı: [Biriya’s love and tragedy] South Azerbaijani literature: Research. Book IV. Baku: "ULU” IKF, 2017, 160 p.

3. Qəribli İslam. Talesiz şair. Məhəmməd Biriya [Unlucky poet. Muhammad Biriya] Works. Baku: 'Science', 2010, P. $4-27$

4. M. Briya. Şair ömrünün elçiləri [Ambassadors of the poet's life] Baku: "Yurd”, 2003, 208 p. 